\title{
IMPLEMENTASI PENDIDIKAN KARAKTER SECARA TERINTEGRASI DALAM PEMBELAJARAN MENULIS KARANGAN DESKRIPSI DI KELAS XI TIK SMK NEGERI 2 KEPAHIANG
}

\author{
Alam Sahri \\ alamsahri@yahoo.co.id
}

\begin{abstract}
Tujuan penelitian ini adalah untuk mengetahui implementasi pendidikan karakter secara terintegrasi dalam pembelajaran menulis karangan deskripsi di kelas XI TIK SMK Negeri 2 Kepahiang yang meliputi kegiatan perencanaan, pelaksanaan, dan evaluasi pembelajaran. Penelitian ini berjenis penelitian deskriptif kualitatif. Teknik pengumpulan data menggunakan observasi, dokumentasi, rekaman, dan wawancara. Hasil penelitian dan pembahasan menunjukkan pada kegiatan perencanaan implementasikan pendidikan karakter sudah terintegrasi dalam bentuk menyusun silabus dan RPP berkarakter. Implementasikan pendidikan karakter pada kegiatan pelaksanaan pembelajaran dilakukan melalui ucapan langsung serta tingkah laku guru dan siswa yang sesuai dengan indikator pelaksanaan pendidikan karakter. Nilai pendidikan karakter yang belum diimplementasikan dalam kegiatan ini adalah cinta damai dan peduli lingkungan. Implementasi pendidikan karakter pada kegiatan evaluasi dilakukan pada proses evaluasi. Sedangkan pada hasil evaluasi belum diimplementasikan. Simpulan penelitian ini adalah pada kegiatan perencanaan pendidikan karakter sudah diimplementasikan secara optimal oleh guru, kegiatan pelaksanaan pembelajaran pendidikan karakter sudah diimplementasikan secara optimal oleh guru dan siswa, tetapi pada evaluasi pembelajaran pendidikan karakter belum diimplementasikan secara optimal karena pembelajaran hanya berfokus pada penilaian hasil belajar.
\end{abstract}

Key words: Implementasi, Pendidikan Karakter, Pembelajaran Terintegrasi, Menulis, Karangan Deskripsi.

\section{Pendahuluan}

Fenomena yang terjadi akhirakhir ini di setiap sekolah adalah masalah degradasi moral siswa. Setiap hari kita sering mendengar adanya berita mengenai kenakalan remaja, tawuran, tindak asusila yang terjadi di kehidupan kita yang disebabkan karena ulah siswa atau remaja. Jika kita menilik ke belakang pada waktu sebelum era reformasi para siswa sangat santun terhadap guru dan eleman masyarakat yang ada di sekitar sekolah. Budaya 3 S (Sapa, Senyum, Salam) selalu digerakkan di setiap sekolah. Hasilnya dirasakan cukup efektif dalam menanamkan nilai-nilai karakter kepada siswa dan membendung tindakan-tidakan yang tidak baik dari para siswa. Tidak jelas alasannya mengapa budaya $3 \mathrm{~S}$ tersebut semakin hari semakin ditinggalkan bahkan sampai saat ini jarang kita menemui sekolah yang masih mempertahankan budaya tersebut.

Fakta tersebut bukan hanya disebabkan oleh siswa, kualitas sikap guru pun sekarang perlu dipertanyakan. Tidak heran jika kita mendengar adanya oknum guru yang melakukan tindakan asusila bahkan mencoreng nama baik sebagai seorang guru. Guru melarang siswa untuk merokok di lingkungan 
sekolah, faktanya guru sendiri merokok di lingkungan sekolah. Apakah seorang guru sudah berjalan sesuai dengan nilainilai karakter yang baik atau malah sebaliknya? Pertayaan tersebut harus kita renungkan dalam-dalam. Lembaga pencetak guru seharusnya lebih selektif dalam menerima calon guru. Calon guru harus didik dengan penggembelengan khusus seperti sekolah-sekolah kedinasan seperti IPDN atau STAN. Calon guru harus memiliki kemampuan khusus bidang keguruan dan kualitas sikap yang baik dengan demikian guru merupakan sosok yang dapat dicontoh dan ditiru semua tingkah lakunya.

Revolusi mental guru dan siswa perlu segera dilaksanakan untuk mencapai kualitas sikap guru dan siswa yang baik dan akan menghasilkan suatu sinergi dalam kehidupan menuju dunia pendidikan yang berkarakter, semua itu akan memberikan angin segar bagi dunia pendidikan kita saat ini. Dengan keadaan tersebut degradasi moral siswa dan guru akan sedikit berkurang. Salah satu bentuk inovasi dalam pembelajaran adalah dengan mengintegrasikan pembelajaran dengan nilai-nilai pendidikan karakter.

Fakta menarik ditemukan juga di lapangan. Setiap guru dalam mengajar selalu menanamkan karakter yang baik bagi setiap siswa. Tidak ada guru yang mengajarkan karakter yang tidak baik seperti merusak alam, tidak menghargai sesama dan masih banyak lagi. Tingkah laku guru pun sopan dalam pembelajaran dan dapat ditiru oleh seluruh siswa. Pertanyaan besar mengapa karakter siswa tidak juga membaik padahal guru sudah memiliki karakter baik? Untuk itu penelitian ini akan membahas integrasi nilai-nilai pendidikan karakter dalam pembelajaran dengan sumber data guru dan siswa SMK Negeri 2 Kepahiang

Penelitian ini akan membahas tentang integrasi nilai-nilai pendidikan karakter dengan pembelajaran yaitu pembelajaran menulis karangan deskripsi yang merupakan salah satu bentuk karangan yang sulit ditulis siswa dengan alasan sulit untuk memberikan gambaran mendetail sehingga membangkitkan impresi pada pembacanya dan pembaca seolah-olah diajak untuk merasakan, melihat, dan menikmati objek yang sedang digabarkan tersebut.

Sebelum melakukan integrasi pendidikan karakterseorang guru harus melakukan implementasi atau perencanaan yang matang sehingga mencapai tujuan yang diinginkan. Integrasi nilai-nilai pendidikan karakter ini dapat dilakukan oleh seorang guru melalui beberapa tahapan yaitu tahap perencanaan, pelaksanaan, dan evaluasi pembelajaran.

Penelitian yang serupa sudah dilakukan oleh catur Hadi Setyawan dengan judul "Implementasi Pendidikan Karakter dalam Pembelajaran Bahasa Indonesia Di SMA Negeri 1 Bantul" tahun 2015 dari Universitas Negeri Yogyakarta dan Haifa Maria dengan judul "Implementasi Pendidikan Karakter dalam Pembelajaran Bahasa dan Sastra Indonesia Di SMA Negeri 8 Malang" tahun 2013 dari Universitas Negeri Malang.

Kedua penelitian ini hanya membahas masalah implementasi pendidikan karakter dalam pembelajaran bahasa Indonesia secara umum belum terpusat pada satu kompetensi dasar. Untuk itu penelitian ini akan berusaha memfokuskan pada satu kompetensi 
dasar yaitu menulis wacana atau karangan yang bercorak deskriptif. Kelebihan kedua penelitian ini adalah data disajikan secara jelas sehingga simpulan akhir yang didapatkan bisa dipertanggung jawabkan.

Penelitian ini mengambil setting penelitian di SMK Negeri 2 Kepahiang dengan alasan bahwa sekolah tersebut merupakan sekolah baru yang ada di Kabupaten Kepahiang. Sekolah ini berdiri sejak tahun 2006. Pada awal berdiri sekolah ini hanya memiliki 160 siswa dengan empat ruang belajar dan dua jurusan yaitu jurusan TIK (Multimedia), dan Teknik Kendaraan Ringan. Seiring berjalannya waktu sekolah ini terus berkembang sehingga pada tahun pelajaran 2015/2016 sudah memiliki 800 siswa dengan 33 ruang belajar dan 6 jurusan.

Para siswa yang sekolah di sini memiliki karakter yang sangat berbeda dengan sekolah-sekolah lain yang ada di Kabupaten Kepahiang. Perbedaan karakter tersebut terlihat pada jumlah siswa yang bermasalah setiap hari terus bertambah. Masalah tersebut adalah tidak mematuhi peraturan sekolah dan kurangnya rasa tanggung jawab jika diberikan tugas oleh guru.

\section{METODE PENELITIAN}

Penelitian ini menggunakan meode deskriptif kualitatif. Data dalam penelitian ini adalah implementasi pendidikan karakter yang terdapat dalam dokumentasi silabus, RPP, dan hasil evaluasi, ujaran siswa dan guru (wacana kelas) yang diambil dua kali pertemuan dengan kelas yang berbeda, hasil wawancara dengan guru dan siswa, sumber data dalam penelitian ini adalah dokumentasi silabus, RPP, dan hasil evaluasi, satu orang guru bahasa Indonesia dan siswa kelas XI tik SMK Negeri 2 Kepahiang. Teknik pengumpulan data dalam penelitian ini adalah observasi, wawancara, dokumentasi, rekaman. Instrument penelitian ini adalah lembar observasi dan panduan wawancara. Teknik analisis data dalam penelitian ini adalah transkripsi data, reduksi data, klasifikasi data, penarikan simpulan awal, triangulasi, dan penarikan simulant akhir. Uji validasi data penelitian ini menggunakan triangulasi.

\section{Hasil Dan Pembahasan}

Suatu rencana akan berjalan dengan lancar apabila sudah tersusun dengan baik semua yang akan dilakukan tersebut. Jika suatu rencana mendapatkan suatu halangan atau hampabatan dalam pelaksanaannya, bisa jadi terdapat ketidak cocokan antara bagian-bagian yang sudah direncanakan tersebut. Pendidikan karakter dalam penelitian ini merupakan suatu rencana, apabila dalam pelaksaannya nanti pendidikan karakter tidak sesuai dengan apa yang direncanakan sehingga terjadi kesia-siaan dalam pelaksanaannya.

Pendidikan karakter akan diimplementasikan dalam pembelajaran bahasa Indonesia khususnya menulis karangan deskripsi. Dalam implementasi ini, diharapkan pendidikan karakter yang diintegrasikan ke dalam pembelajaran menulis karangan deskripsi akan berjalan dengan lancar. Untuk itu diperlukan kesiapan yang atang dari seorang guru dalam merancang materi menulis karangan deskripsi yang akan diajarkan kepada siswa. Perencanaan tersebut meliputi pemilihan tema yang sesuai 
dengan karakter yang akan dicapai dalam pembelajaran tersebut.

$$
\text { Pengertian implementasi }
$$

menurut Usman (2002: 70) implementasi adalah bermuara pada aktivitas, aksi, tindakan atau adanya mekanisme suatu sistem, implementasi bukan sekedar aktivitas, tetapi suatu kegiatan yang terencana dan untuk mencapai tujuan kegiatan. Dari pendapat di atas jelas bahwa implementasi bermuara pada mekanisme suatu sistem. Pengertian mekanisme disini mengandung arti bahwa implementasi bukanlah merupakan sekedar aktivitas, tetapi lebih menekankan pada suatu kegiatan yang dilakukan dengan perencanaan yang matang dan sungguh-sungguh berdasarkan acuan norma tertentu untuk mencapai tujuan kegiatan yaitu pengintegrasian pendidikan karakter dalam pembelajaran karangan deskripsi di SMK Negeri 2 Kepahiang.

Pendapat lain dikemukankan juga oleh Harsono (2002: 67) implementasi adalah suatu proses untuk melaksanakan kegiatan menjadi tindakan kebijakan dari politik ke dalam administrasi. Pengembangan suatu kebijakan dalam rangka penyempurnaan suatu program. Hal senada juga diungkapkan oleh Setiawan (2004: 39) implementasi adalah perluasan aktivitas yang saling menyesuaikan proses interaksi antara tujuan dan tindakan untuk mencapainya serta memerlukan jaringan pelaksana, birokrasi yang efektif.

Dari tiga pendapat di atas dapat disimpulkan bahwa implementasi adalah adalah pelaksanaan atau penerapan suatu rencana yang telah disusun dengan sungguh-sungguh dengan harapan orang lain bisa menerima dan melakukan perubahan terhadap suatu pembelajaran sehingga bisa mendapatkan hasil yang didapatkan.

Implementasi pada pembelajaran bahasa Indonesia dengan integrasi pendidikan karakter dimulai dari tahap perencanaan yaitu dengan memodifikasi silabus dan rancangan pelaksanaan pembelajaran. Setelah itu pada tahap pelaksanaan pembelajaran, guru harus memilih model pembelajaran yang sesuai dengan tema yang akan diajarkan. Pemilihan model pembelajaran ini harus dengan perencanaan yang sungguhsungguh agar didapatkan model pembelajaran yang sesuai dengan apa yang telah direncanakan. Tahapan selanjutnya adalah pada tahap evaluasi. Guru harus melakukan evaluasi, evaluasi dilakukan bukan hanya pada aspek kognitif tetapi juga pada aspek afektif dan psikomotor.

Pendidikan adalah suatu usaha untuk mengembangkan potensi peserta didik secara optimal (Wahyuni, 2012: 2). Pendapat ini mengandung arti bahwa semua potensi yang ada di dalam diri para peserta didik dapat dikembangkan dengan pendidikan, banyak pendidikan yang dikembangkan di Indonesia. Misalnya pendidikan budaya, pendidikan budi pekerti, dan pendidikan karakter. Akhir-akhir ini dunia pendidikan kita sedang mengalami suatu kemunduran.

Bangsa Indonesia dikenal sebagai bangsa yang berkarakter baik, bermoral, beretika, berakhlak mulia, sehingga dimenjadi panutan bagi bangsa-bangsa lain. Tetapi kenyataan itu sekarang mulai pudar seiring era globalisasi yang melanda saat ini. Karaker yang mulia yang dimiliki bangsa Indonesia sudah jarang ditemukan. Sesama warga sering bertengkar, berkelahi, saling menghujat, dan akhirnya memunculkan perang 
SARA. Padahal seharusnya, karakter yang baik tersebut menjadi modal dasar dalam membangun peradaban tingkat tinggi.

Karakter menurut Damayanti (2014: 11) adalah cara berpikir dan berprilaku yang menjadi ciri khas tiap individu untuk hidup dan bekerjasama, baik dalam lingkungan keluarga, masyarakat, bangsa dan Negara. Pendapat lain juga dikemukakan oleh Abidin (2012: 53) karakter adalah berasal dari bahasa Yunani kasairo yang berarti cetak biru atau format dasar.

Beradasarkan asal katanya karakter dianggap sebagai sekumpulan kondisi yang dimiliki seseorang. Kondisi ini bisa saja bersifat bawaan ataupun bentukan. Pengertian karakter dipertegas lagi oleh Fathurrohman, dkk (2013: 17) mengatakan bahwa karakter adalah berasal dari bahasa Yunani yang berarti to mark atau menandai dan memfokuskan bagaimana mengaplikasikan nilai-nilai kebaikan dalam bentuk tindakan atau tingkah laku, sehingga orang yang tidak jujur, kejam, rakus, dan prilaku jelek lainnya dikatakan orang yang berkarakter jelek.

Sebaliknya, orang yang berprilaku sesuai dengan kaidah moral disebut dengan berkarakter mulia. Secara etimologis, kata karakter bisa berarti sifat-sifat kejiwaan, akhlak dan budi pekerti yang membedakan seseorang. Dari tiga pendapat di atas bisa disimpulkan bahwa karakter adalah ciri khas setiap individu yang membedakan dengan individu lain dan mengaplikasikannya dalam kehidupan bermasyarakat, berbangsa, dan benegara, ciri khas ini merupakan hasil bentukan atau bawaan dari setiap individu tersebut.
Pendidikan karakter menurut Abidin (2012: 56) adalah dimaknai sebagai pendidikan yang mengembangkan nilai-nilai karakter pada diri peserta didik sehingga mereka memiliki nilai dan karakter sebagai karakter dirinya, menerapkan nilai-nilai tersebut dalam kehidupan dirinya, sebagai anggota masyarakat dan warga negara yang religius, nasionalis, produktif, dan kreatif. Pendapat di atas diperkuat lagi oleh Damayanti (2014: 11) mengatakan bahwa pendidikan karakter adalah gerakan nasional menciptakan sekolah yang membina etika, bertanggung jawab dan merawat orangorang muda dengan pemodelan dan mengajarkan karakter baik melalui penekanan pada universal, nilai-nilai yang kita yakini. Damayanti (2014: 12) juga menambahkan pengertian pendidikan karakter, pendidikan karakter merupakan suatu usaha yang direncanakan secara bersama yang bertujuan menciptakan generasi penerus yang memiliki dasar-dasar pribadi yang baik, baik dalam pengetahuan (cognitive), perasaan (feeling), dan tindakan (action).

Lebih tegas lagi Lickona (dalam Gunawan, 2012: 23) berpendapat bahwa pendidikan karakter adalah pendidikan untuk membentuk kepribadian seseorang melalui pendidikan budi pekerti, yang hasilnya terlihat dalam tindakan nyata seseorang, yaitu tingkah laku yang baik, jujur, bertanggung jawab, menghormati hak orang lain, kerja keras, dan sebagainya. Selain pendapat tersebut Elkind dan Sweet (dalam Gunawan, 2012: 23) mengatakan pendidikan karakter adalah:

"Character education is the deliberate effort to help people 
understand, care about, and act upon core ethical valuaes, when we think about the kind of character we want for our children, it is clear that we want them to be able to judge what is right, care deeply about what is right, and then do what they believe to be right, even in the face of pressure from without and temptation from within".

Menurut pendapat ini pendidikan karakter adalah upaya yang disengaja untuk membantu memahami manusia, peduli dan inti atas nilai-nilai etis atau susila. Dimana kita berpikir tentang macam-macam karakter yang kita inginkan untuk anak kita, ini jelas bahwa kita ingin mereka mampu untuk menilai apa itu kebenaran, sangat peduli tentang apa itu kebenaran atau hak-hak, dan kemudian melakukan apa yang mereka percaya menjadi yang sebenarnya, bahkan dalam menghadapi tekanan dari tanpa dan dalam godaan.

Pendapat lain yang menyatakan pengertian pendidikan karakter adalah menurut Ramli (dalam Fathurrohman, dkk, 2013: 15) pendidikan karakter memiliki esensi dan makna yang sama dengan pendidikan moral dan pendidikan akhlak. Tujuannya adalah membentuk pribadi anak, supaya menjadi manusia yang baik, warga msyarakat, dan warga negara yang baik. Selain itu Kevin Ryan dan Bohlin dalam Fathurrohman, dkk (2014: 17) mempertegas lagi pengertian pendidikan karakter adalah "sebagai usaha yang sungguh-sungguh untuk membantu seseorang memahami, peduli, dan bertindak dengan landasan inti nilai-nilai etis".

Berdasarkan pendapat-pendapat di atas dapat disimpulkan pendidikan karakter adalah gerakan nasional yang dilakukan pada tiap sekolah sebagai suatu usaha sadar dan terencanakan secara matang dan sungguh-sungguh secara bersama untuk mencapai generasi penerus yang memiliki sikap dan tingkah laku yang baik, jujur, dan bertanggung jawab, menghormati hak orang lain, dan kerja keras, sehingga generasi penerus kita menjadi generasi yang berkarakter baik atau mulia.

Pendidikan karakter mempunyai fungsi sebagai pengembangan, perbaikan, penyaring. Menurut Wahyuni (2012: 3) fungsi pendidikan karakter sebagai pengembangan adalah pendidikan karakter bisa dijadikan sebagai alat pengembangan potensi peserta didik untuk menjadi pribadi yang berprilaku baik, pendidikan karakter sebagai perbaikan maksudnya adalah pendidikan karakter dapat memperbaiki prilaku peserta didik dalam pengembangan yang lebih bermanfaat, selanjutnya sebagai penyaring maksudnya adalah pendidikan karakter dapat digunakan sebagai alat untuk menyaring budaya bangsa sendiri dan budaya bangsa lain yang tidak sesuai dengan nilai-nilai budaya dan karakter yang bermartabat. Ketiga fungsi ini akan berhasil dengan baik apabila didukung oleh semua elemen pendidikan termasuk juga orang tua siswa. Oleh karena itu, Pendidikan karakter bukan hanya tanggung jawab dari guru tetapi tenggung jawab kita bersama sebagai warga negara Indonesia.

Selain berfungsi sebagai pengembangan, perbaikan, dan penyaring, pendidikan karakter juga mempunyai tujuan. Tujuan tersebut adalah mengembangkan kebiasaan dan prilaku peserta didik yang terpuji sejalan dengan nilai-nilai universal dan tradisi 
karakter bangsa yang religius, mengembangkan potensi kalbu/nurani/ afektif peserta didik sebagai manusia dan warganegara yang memiliki nilai-nilai karakter dan karakter bangsa, menanamkan jiwa kepemimpinan dan bertanggungjawab peserta didik sebagai generasi penerus bangsa, mengembangkan kemampuan peserta didik menjadi manusia yang mandiri, kreatif, berwawasan kebangsaan, mengembangkan lingkungan kehidupan sekolah sebagai lingkungan belajar yang aman, jujur, penuh kreativitas dan persahabatan, serta dengan rasa kebangsaan yang tinggi dan penuh kekuatan (dignity) Fathurrohman, dkk (2013: 97-98). Pendapat yang lain juga dikemukakan oleh Muslich, menurut Muslich (2011: 81) menyatakan bahwa tujuan pendidikan karakter adalah

"untuk meningkatkan mutu penyelengaraan dan hasil pendidikan yang mengarah kepada pencapaian pembentukan pendidikan karakter dan ahlak mulia peserta didik secara utuh, terpadu, dan seimbang". Semua tujuan ini akan dapat tercapai dengan baik apabila direncanakan dan diimplementasikan dengan sungguhsungguh pada setiap mata pelajaran.

Nilai-nilai pendidikan karakter yang harus dikembangkan dalam setiap pembelajaran terdiri dari delapan belas nilai. Nilai-nilai tersebut bersumber dari agama, pancasila, budaya, dan tujuan pendidikan nasional (Kemendiknas, 2011: 8). Berikut ini adalah nilai-nilai pendidikan karakter serta deskripsi yang bisa dikembangkan dalam semua jenjang pendidikan.

Tabel 1. Nilai dan Deskripsi Pendidikan Karakter yang Dapat Diintegrasikan dalam Setiap Mata Pelajaran

\begin{tabular}{|l|l|}
\hline \multicolumn{1}{|c|}{ NILAI } & \multicolumn{1}{c|}{ DESKRIPSI } \\
\hline Religius & $\begin{array}{l}\text { Sikap dan prilaku yang patuh dalam melaksanakan ajaran } \\
\text { agama yang dianutnya, toleran terhadap pelaksanaan ibadah } \\
\text { agama lain, dan hidup rukun dengan pemeluk agama lain. }\end{array}$ \\
\hline Jujur & $\begin{array}{l}\text { Perilaku yang didasarkan pada upaya menjadikan dirinya } \\
\text { sebagai orang yang selalu dapat dipercaya dalam perkataan, } \\
\text { tindakan, dan pekerjaan. }\end{array}$ \\
\hline Toleransi & $\begin{array}{l}\text { Sikap dan tindakan yang menghargai perbedaan agama, suku, } \\
\text { etnis, pendapat, sikap, dan tindakan orang lain yang berbeda } \\
\text { dari dirinya. }\end{array}$ \\
\hline Disiplin & $\begin{array}{l}\text { Tindakan yang menunjukkan perilaku tertib dan patuh pada } \\
\text { berbagai ketentuan dan peraturan. }\end{array}$ \\
\hline Kerja Keras & $\begin{array}{l}\text { Perilaku yang menunjukkan upaya sungguh-sungguh dalam } \\
\text { mengatasi berbagai hambatan belajar dan tugas, serta } \\
\text { menyelesaikan tugas dengan sebaik-baiknya. }\end{array}$ \\
\hline Kreatif & $\begin{array}{l}\text { Berpikir dan melakukan sesuatu untuk menghasilkan cara atau } \\
\text { hasil baru dari sesuatu yang telah dimiliki. }\end{array}$ \\
\hline Mandiri & $\begin{array}{l}\text { Sikap dan prilaku yang tidak mudah tergantung pada orang lain } \\
\text { dalam menyelesaikan tugas-tugas. }\end{array}$ \\
\hline Demokratis & $\begin{array}{l}\text { Cara berpikir, bersikap, dan bertindak yang menilai sama hak } \\
\text { dan kewajiban dirinya dan orang lain. }\end{array}$ \\
\hline
\end{tabular}




\begin{tabular}{|l|l|}
\hline \multicolumn{1}{|c|}{ NILAI } & \multicolumn{1}{|c|}{ DESKRIPSI } \\
\hline Rasa Ingin Tahu & $\begin{array}{l}\text { Sikap dan tindakan yang selalu berupaya untuk mengetahui } \\
\text { lebih mendalam dan meluas dari sesuatu yang dipelajarinya, } \\
\text { dilihat, dan didengar. }\end{array}$ \\
\hline Semangat kebangsaan & $\begin{array}{l}\text { Cara berpikir, bertindak, dan berwawasan yang menempatkan } \\
\text { kepentingan bangsa dan Negara di atas kepentingan diri dan } \\
\text { kelompoknya. }\end{array}$ \\
\hline Cinta Tanah Air & $\begin{array}{l}\text { Cara berpikir, bersikap, dan berbuat yang menunjukkan } \\
\text { kesetiaan, kepedulian, dan penghargaan yang tinggi terhadap } \\
\text { bahasa, lingkungan fisik, sosial, budaya, ekonomi, dan politik } \\
\text { bangsa. }\end{array}$ \\
\hline Menghargai Prestasi & $\begin{array}{l}\text { Sikap dan tindakan yang mendorong dirinya untuk } \\
\text { menghasilkan sesutau yang berguna bagi masyarakat, dan } \\
\text { mengakui, serta menghormati keberhasilan orang lain. }\end{array}$ \\
\hline Bersahabat/Komunikatif & $\begin{array}{l}\text { Tindakan yang memperlihatkan rasa senang berbicara, bergaul, } \\
\text { dan bekerja sama dengan orang lain. }\end{array}$ \\
\hline Cinta Damai & $\begin{array}{l}\text { Sikap, perkataan, dan tindakan yang menyebabkan orang lain } \\
\text { merasa senang dan aman atas kehadiran dirinya. }\end{array}$ \\
\hline Gemar Membaca & $\begin{array}{l}\text { Kebiasaan menyediakan waktu untuk membaca berbagai } \\
\text { bacaan yang memberikan kebijakan bagi dirinya. }\end{array}$ \\
\hline Peduli Lingkungan & $\begin{array}{l}\text { Sikap dan tindakan yang selalu berupaya mencegar kerusakan } \\
\text { pada lingkungan alam di sekitarnya, dan mengembangkan } \\
\text { upaya-upaya untuk memperbaiki kerusakan alam yang sudah } \\
\text { terjadi. }\end{array}$ \\
\hline Tanggung Jawab & $\begin{array}{l}\text { Sikap dan tindakan yang selalu ingin memberi bantuan kepada } \\
\text { orang lain dan masyarakat yang membutuhkan. }\end{array}$ \\
\hline $\begin{array}{l}\text { Sikap dan perilaku seseorang untuk melaksanakan tugas dan } \\
\text { kewajibannya, yang seharusnya dia lakukan, terhadap diri } \\
\text { sendiri, masyarakat, lingkungan (alam, sosial, dan budaya), } \\
\text { negara dan Tuhan Yang Maha Esa. }\end{array}$ \\
\hline
\end{tabular}

Kemendiknas (dalam Abidin, 2012: 67-68)

Pendidikan karakter dapat diintegrasikan dalam setiap mata pelajaaran khususnya bahasa Indonesia. Dalam pembalajaran bahasa Indonesia empat keterampilan berbahasa sangat terlibat aktif untuk semua aspek dan konkarangan kehidupan. Empat keterampilan berbahasa ini disajikan secara terpadu, melalui pembelajaran terpadu inilah pendidikan karakter dapat diintegrasikan ke dalam pembelajaran bahasa Indonesia yang memiliki cakupan luas dan menjadi semakin mudah. Selain itu, dengan kemudahan dan keluasan pengintegrasian pendidikan karakter dalam pembelajaran bahasa Indonesia, pendidikan karakter juga dapat diperoleh dengan penerapan prinsip-prinsip pendekatan kontekstual (Contextual Teaching and Learning) serta dengan pembelajaran yang disajikan secara tematik.

Menurut Zuchdi (2013: 30) pembelajaran terintegrasi beranjak dari suatu tema sebagai pusat perhatian, yang digunakan untuk menguasai 
berbagai konsep dan keterampilan. Dari pendapat tersebut jelas bahwa untuk mengintegrasikan pendidikan karakter ke dalam pembelajaran harus dipilih tematema yang dapat mendukung pelaksanaan pendidikan karakter tersebut sehingga diharapkan pembelajaran bahasa Indonesia yang berintegrasi dengan pendidikan karakter memberikan pengalaman bermakna bagi peserta didik.

Integrasi pendidikan karakter merupakan pengenalan nilai- nilai, fasilitas diperolehnya kesadaran akan pentingnya nilai-nilai, dan penginternalisasian nilai-nilai ke dalam tingkah laku peserta didik sehari-hari melalui proses pembelajaran baik yang berlangsung di dalam maupun diluar kelas pada mata pelajaran bahasa Indonesia.

Integrasi pendidikan karakter dalam pembelajaran bahasa Indonesia dimulai dari kegiatan perencanaan pembelajaran, kegiatan pelaksanaan pembelajaran, dan kegiatan evaluasi pembelajaran. Semua kegiatan di atas akan dijelaskan di bawah ini:

\section{Kegiatan}

Perencanaan

Pembelajaran Bahasa Indonesia

Perencanaan pembelajaran

bahasa Indonesia dengan integrasi pendidikan karakter dimulai dari modifikasi silabus pembelajaran bahasa Indonesia. Menurut Salim (dalam Gunawan, 2012: 287) silabus adalah secara sederhana istilah silabus dapat dimaknai sebagai garis besar, ringkasan, ikhtisar, atau pokok-pokok isi atau materi pembelajaran. Menurut Majid (dalam Gunawan, 2012: 278) silabus merupakan rancangan pembelajaran yang berisi rancangan bahan ajar, pada mata pelajaran, jenjang dan kelas tertentu, sebagai hasil dan seleksi, pengelompokan, pengurutan dan panyajian materi kurikulum, yang dipertimbangkan berdasarkan ciri dan kebutuhan satuan pendidikan. pendapat serupa juga dikemukakan oleh Mulyasa (dalam Gunawan, 2012: 279) silabus merupakan rencana pembelajaran pada suatu kelompok mata pelajaran tertentu, dengan tema tertentu, yang mencakup standar kompetensi dan kompetensi dasar (SKKD), indikator, materi pembelajaran, penilaian, alokasi waktu, dan sumber belajar. Dari ketiga pendapat di atas dapat disimpulkan bahwa silabus adalah rancangan pembelajaran secara garis besar yang didalamnnya terdapat rancangan bahan ajar, jenjang dan kelas tertentu, standar kompetensi dan kompetensi dasar (SKKD), indikator, materi pembelajaran, alokasi waktu, dan sumber belajar.

Silabus ini sangat penting dalam kegiatan belajar mengajar. Silabus pembelajaran bermanfaat sebagai pedoman dalam pengembangan pembelajaran, pengelolaan kegiatan pembelajaran dan pengembangan sistem penilaian (Gunawan, 2012: 279). Silabus pembelajaran juga dapat dikembangkan disesuaikan dengan kebutuhan lingkungan sekolah masing-masing. Pengambangan silabus mata pelajaran bahasa Indonesia harus memperhatikan prinsip-prinsip pengembangan silabus. Prinsip-prinsip tersebut adalah ilmiah, relevan, sistematis, konsisten, memadai, aktual dan konkarangantual, fleksibel, dan menyeluruh.

Setelah melakukan modifikasi tehadap silabus, tahap perencanaan selanjutnya adalah dengan membuat Rencana Pelaksanaan Pembelajaran 
(RPP). Menurut Mulyasa (dalam Gunawan, 2012: 298) rencana pelaksanaan pembelajaran pada hakikatnya rencana pelaksanaan pembelajaran merupakan rencana jangka pendek untuk memperkirakan atau memproyeksikan apa yang akan dilakukan di dalam proses pembelajaran. Pendapat lain dikemukakan oleh Wahyuni (2012: 69), menurut Wahyuni rencana pelaksanaan pembelajaran merupakan perencanaan jangka pendek untuk memperkirakan tindakan yang akan dilakukan dalam kegiatan pembelajaran. Dari dua pendapat di atas bisa disimpulkan bahwa rencana pelaksanaan pembelajaran adalah rencana jangka pendek untuk memperkirakan atau memproyeksikan tindakan yang akan dilakukan dalam kegiatan pembelajaran.

$$
\text { Rencana Pelaksanaan }
$$

Pembelajaran (RPP) harus diadaptasi sehingga menciptakan pembelajaran yang berwawasan pada pengembangan karakter. Adaptasi rencana pelaksanaan pembelajaran meliputi penambahan dan atau modifikasi kegiatan pembelajaran sehingga ada kegiatan pembelajaran yang mengembangkan karakter, penambahan dan atau modifikasi indikator pencapaian sehingga ada indikator yang terkait dengan pencapaian peserta didik dalam hal karakter, penambahan dan atau modifikasi teknik penilaian sehingga ada teknik penilaian yang dapat mengembangkan dan atau mengukur perkembangan karakter (Gunawan, 2012: 226).

Kegiatan yang dilakukan pada perencanaan pembelajaran ini adalah menyiapkan silabus dan Rencana Pelaksanaan Pembelajaran (RPP) berkarakter. Pada pembelajaran menulis karang deskripsi ini pendidikan karakter diintegrasikan pada silabus dengan membuatkan kolom tersendiri yang letaknya di samping kolom kegiatan pembelajaran. Dalam silabus kelas XI SMK ini nilai pendidikan karakter yang diintegrasikan adalah kreatif, mandiri, menghargai prestasi, dan demokratis.

Integrasi pendidikan karakter yang terdapat dalam Rancangan Pelaksanaan Pembelajaran (RPP) pada bagian kegiatan pembelajaran untuk kompetensi menulis karangan deskripsi adalah peduli sosial, peduli lingkungan, mandiri, kerja keras, rasa ingin tahu, jujur, semangat kebangsaan, dan disiplin.

2. Kegiatan Pelaksanaan Pembelajaran Bahasa Indonesia

Pelaksanaan pembelajaran bahasa Indonesia dengan pengintegrasian nilainilai pendidikan karakter merupakan perwujudan dari silabus, dan rancangan pembelajaran yang telah dibuat oleh guru. Pada tahap ini semua yang kita rencanakan harus diwujudkan sehingga tujuan untuk membuat perubahan pada prilaku siswa akan tercapai.

$$
\text { Pengintegrasian pendidikan }
$$
karakter dalam pembelajaran menurut Gunawan (20012: 215) adalah guru perlu menanamkan nilai-nilai dalam proses pembelajaran dengan cara memberikan teladan kepada peserta didik dengan nilai-nilai karakter tersebut. Setiap kali mengajar guru harus memasukan nilainilai karakter sehingga tercipta pembelajaran bahasa Indonesia yang aktif, kreatif, inovatif, menyenangkan, dan bermanfaat bagi perkembangan karakter siswa tersebut ke arah yang lebih baik. 
Integrasi pendidikan karakter dalam kegiatan pembelajaran menulis karangan deskripsi adalah sebagai berikut:

1. Nilai pendidikan karakter religius. Nilai pendidikan ini diimplementasikan oleh guru dalam bentuk mendo'akan orang lain dengan mengucapkan salam dan memulai pekerjaan dengan menyebut nama Allah. Kegiatan yang dilakukan adalah berdo'a sebelum dan sesudah memulai pembelajaran.

2. Nilai pendidikan karakter jujur. Nilai ini diimplementasikan dengan menyampaikan apa yang dilihatnya dan mengatakan hal yang sebenarnya.

3. Nilai pendidikan toleransi. Nilai ini diimplementasikan secara langsung oleh guru kepada siswa untuk selalu bertoleransi dengan sesama teman di kelas.

4. Nilai pendidikan karakter disiplin. Nilai ini diimplemantasikan dengan guru menegur siswa yang tidak merapikan baju dan siswa yan ditegur dengan penuh kesadaran melaksanakan perintah tersebut.

5. Nilai pendidikan karakter kerja keras. Nilai ini diimplementasikan oleh siswa dengan bersungguh-sungguh dan berusaha sekuat tenaga untuk menjawab pertanyaan dari guru dan pertanyaan dari siswa ketika diskusi kelas berlangsung.

6. Nilai pendidikan karakter kreatif. Nilai ini diimplementasikan dengan cara siswa mempunyai inisiatif untuk memecahkan masalah.

7. Nilai pendidikan karakter mandiri. Nilai ini diimplementasikan dengan guru memiliki keyakinan akan kemampuan siswa secara mandiri menyelesaikan karangan deskripsi berdasarkan gambar.
8. Nilai pendidikan karakter demokratis. Nilai ini diimplementasikan dengan cara guru memberikan kesempatan kepada siswa untuk bekerja kelompok menyelesaikan masalah secara kelompok.

9. Nilai pendidikan karakter rasa ingin tahu. Nilai ini diimplementasikan dengan wujud kegiatan bertanya dari guru ke siswa, siswa ke guru, dan dari siswa ke siswa.

10. Nilai pendidikan karakter semangat kebangsaan. Nilai ini diimplementasikan dengan memberikan pujian karena ruang kelas banyak terdapat gambar pahlawan. Memasang gambar pahlawan ini merupakan upaya untuk menumbuhkan semangat kebangsaan siswa.

11. Nilai pendidikan karakter cinta tanah air. Nilai ini diimplementasikan dengan cara menanyakan lagu-lagu daerah serta lagu wajib nasional yang diketahui oleh siswa dan siswa wajib menghafalnya.

12. Nilai pendidikan karakter menghargai prestasi. Nilai ini diimplementasikan dengan memberikan penguatan verbal berupa ucapan "Bagus" dan "Terimakasih" dari guru untuk siswa yang telah berhasil menjawab pertanyaan guru dengan benar.

13. Nilai pendidikan karakter bersahabat/komunikatif. Nilai ini diimplementasikan dengan cara siswa mampu menanggapi sapaan orang lain, menjawab pertanyaan orang lain dan mampu berkomunikasi dengan baik.

14. Nilai pendidikan karakter cinta damai. Nilai pendidikan ini belum diimplementasikan oleh guru dalam pembelajaran. 
15. Nilai pendidikan karakter gemar membaca. Nilai pendidikan karakter ini diimplementasikan dengan ucapan langsung dari guru agar siswa selalu meningkatkan kuantitas membaca.

16. Nilai pendidikan karakter peduli lingkungan. Nilai pendidikan karakter ini belum diimplementasikan dalam pembelajaran.

17. Nilai pendidikan karakter peduli sosial. Nilai pendidikan karakter ini diimplementasikan dengan menanyakan siswa yang tidak masuk kelas dengan alasan tertentu dan memberikan nasehat kepada siswa yang tinggal jauh dari orang tua atau kos.

18. Nilai pendidikan karakter tanggung jawab. Nilai ini diimplementasikan dengan cara siswa bertanggung jawab terhadap semua yang ia katakan selama pembelajaran.

3. Kegiatan Evaluasi Pembelajaran Bahasa Indonesia

Penilaian yang dilakukan adalah dengan melakukan adaptasi pendidikan karakter dalam setiap langkah penilaiannya. Penilaian atau evaluasi dalam pembelajaran yang diintegrasikan dengan pendidikan karakter adalah dengan menggunakan penilaian otentik. Penilaian otentik adalah pengumpulan berbagai data yang bisa memberikan gambaran perkembangan belajar siswa (Abidin, 2012: 62). Dengan penilaian otentik dapat diketahui siswa mengalami kemajuan atau kemunduran dalam pembelajaran. Penilaian otentik sangat terkait dengan pencapaian kompetensi pengetahuan, keterampilan, dan sikap siswa.

Jhonson, Penny, dan Gordon (dalam Abidin, 2012: 63) mengatakan bahwa penilaian otentik pada dasarnya adalah penilaian performa yakni penilaian yang dilakukan untuk mengetahui pengetahuan dan ketarampilan siswa selama proses pembelajaran dalam mencapai produk atau hasil belajar tertentu. Dari pendapat tersebut jelas bahwa dalam menentukan hasil pembelajaran diperlukan suatu alat ukur, alat ukur ini diharapkan mampu mengukur aktivitas perkembangan karakter, alat ukur yang dimaksud adalah penilaian otentik.

Pada kegiatan evaluasi pembelajaran nilai pendidikan karakter belum diimplementasikan pada hasil evaluasi. Hasil evaluasi siswa hanya diberi nilai dan dikomentari tanpa menentukan nilai pendidikan karakter yang muncul dalam karangan deskripsi siswa tersebut. Hanya saja pada saat proses evaluasi pendidikan karakter diintegrasikan. Nilai-nilai tersebut adalah nilai demokratis, toleransi, rasa ingin tahu, dan bersahabat atau komunikatif.

Keterampilan menulis karangan sangat diperlukan oleh setiap siswa, siswa yang memiliki keterampilan menulis karangan akan dengan mudah menuangkan ide-ide yang dimiliki ke dalam bentuk tulisan. Menurut Dalman (2012: 4) menulis adalah proses penyampaian pikiran, angan-angan, perasaan dalam bentuk lambang / tanda / tulisan yang bermakna. Senada dengan pendapat tersebut, Tarigan (dalam Sanddhono dan Slamet, 2012: 98) menulis pada hakikatnya adalah melukiskan lambang-lambang grafis yang menggambarkan suatu bahasa yang dipahami seseorang untuk dibaca orang lain yang dapat memahami bahasa dan lambang-lambang grafis tersebut. Selanjutnya Nurgiantoro (dalam Kusmana, 2010: 99) mengemukakan 
menulis adalah aktivitas mengemukakan gagasan melalui media bahasa tulis. Jadi, secara sederhana dapat disimpulkan menulis adalah proses penyampaian ide, gagasan, atau lambing-lambang bahasa ke dalam bentuk tulisan.

Pengertian karangan deskripsi dikemukakan oleh Finoza (2004: 197198) deskripsi dipungut dari bahasa Inggris "description". Kata ini berhubungan dengan verba "to describe" (melukis dengan bahasa). Dalam bahasa latin, deskripsi dikenal dengan "describere" yang berarti 'menulis tentang' membeberkan suatu hal, melukis suatu hal. Pendapat serupa juga dikemukakan oleh Sami (2003: 41) menyatakan bahwa deskripsi adalah tulisan yang tujuannya memberikan perincian atau detail tentang objek sehingga dapat memberi pengaruh pada sensitivitas dan imajinasi pembaca atau pendengar bagaikan mereka ikut melihat, mendengar, merasakan, atau mengalami langsung objek tersebut. Keraf (1982: 2) juga mengemukakan pendapatnya bahwa deskripsi atau pemerian merupakan sebuah bentuk tulisan yang bertalian dengan usaha para penulis untuk memberikan perincianperincian dari objek yang dibicarakan. Pendapat lain juga dikemukkan juga oleh Dalman (2012: 94) karangan deskripsi merupakan karangan yang melukiskan atau menggambarkan suatu objek atau peristiwa tertentu dengan kata-kata secara jelas dan terperinci sehingga pembaca seolah-olah turut merasakan atau mmengalami langsung apa yang dideskripsikan langsung si penulisnya. Selanjutnya Kusuma (2010: 112) mengemukankan karangan deskripsi atau disebut juga paragraf deskripsi adalah paragraf yang isinya sesuatu berdasarkan hasil pengindaraan. Sanddhono dan Slamet (2012: 110) menyatakan deskripsi adalah ragam wacana yang melukiskan atau menggambarkan sesuatu bberdasarkan kesan-kesan dari pengamatan, pengalaman, dan perasaan penulisnya. Dari pendapat-pendapat di atas dapat disimpulkan bahwa karangan deskripsi adalah suatu karangan yang digunakan untuk memaparkan suatu objek dalam konkarangan sosial dimana pemaparannya membuat pembaca seolah-olah merasakan, melihat, dan mendengar objek yang dibicarakan tersebut.

Berdasarkan pendekatannya karangan deskripsi dibagi menjadi: (a) deskripsi ekspositoris; (b) deskripsi impresionistis. Deskripsi ekspositoris adalah deskripsi yang sangat logis, yang isinya merupakan daftar, rincian, semuanya, atau yang menurut penulisannya hal yang penting-penting saja, yang disusun menurut sistem dan urutan-urutan logis objek yang diamati itu (Dalman, 2012: 97). Sedangkan deksripsi impresionistis atau disebut juga deskriptif simulatif adalah deskripsi yang menggambarkan inspirasi penulisnya, atau untuk menstimulus pembacanya (Dalman, 2012: 98).

Karangan deskripsi dapat dibedakan dari karangan-karangan lain dengan melihat ciri-ciri yang tedapat dalam karangan tersebut. Ciri-ciri karangan karangan dekripsi menurut Keraf (dalam Dalman, 2012: 95) adalah (a) berisi tentang perincian-perincian sehingga objeknya terpandang di depan mata; (b) dapat menimbulkan kesan dan daya khayal pembaca; (c) berisi penjelasan menarik minat serta orang lain atau pembaca; (d) menyampaikan 
sifat dan perincian wujud yang dapat ditemukan dalam objek itu; (e) menggunakan bahasa yang cukup hidup, kuat, dan bersemangat serta kongkret.

Pembelajaran karangan deskripsi harus mamberikan tujuan yang jelas pada diri siswa. Tujuan itu diharapkan dapat diaplikasikan dalam kehidupan sehari-hari siswa. Menurut Widyamartaya (1992: 9-10) karangan deskirpsi harus menyampaikan sesuatu hal dalam urutan yang mendetail dengan maksud untuk menghadirkan di depan mata angan-angan pembaca tentang segala sesuatu yang dilihat, didengar, dikecap, diraba, atau diciumoleh pengarang. Dari pendapat tersebut dapat disimpulkan bahwa karangan deskripsi adalah bentuk tulisan yang bertujuan untuk memperluas pengetahuan dan pengalaman pembaca dengan jalan melukiskan hakikat objek yang sebenarnya.

Tidak semua karangan yang terdapat dalam pembelajaran bahasa Indonesia termasuk jenis karangan deskripsi. Untuk dapat membedakan karangan deskripsi dengan karangankarangan lain dalam pembelajaran bahasa Indonesia kita haruslah memahami ciri-ciri karangan deskripsi. Menurut Semi (2003: 41) ciri-ciri karangan deskripsi adalah deskripsi lebih berupaya memperlihatkan detail atau perincian tentang objek, deskripsi lebih bersifat memberi pengarus sensitivitas dan membentuk imajinasi pembaca. deskripsi disampaikan dengan gaya yang nikmat dengan pilihan kata yang menggugah, deskripsi lebih banyak memaparkan tentang sesuatu yang dapat didengar, dilihat, dan dirasakan, sehingga objeknya pada umumnya berupa benda, alam, warna, dan manusia, organisasi penyampaiannya lebih banyak menggunakan susunan ruang (spartial order).

Karangan deskripsi dibagi menjadi dua jenis, deskripsi sugestif dan deskripsi teknis. Deskripsi sugestif adalah deskripsi yang bertujuan membangkitkan daya khayal, kesan atau sugesti tertentu, seolah-olah pembaca melihat sendiri objek (yang diekspresikan) secara keseluruhan seperti yang dialami secara fisik oleh penulisnya. Sedangkan deskripsi teknis adalah deskripsi yang bertujuan memberikan identifikasi atau informasi objek, sehingga pembaca dapat mengenal bila bertemu atau berhadapan dengan objek. Dari pengertian tersebut dapat disimpulkan bahwa deskripsi sugestif adalah karangan deskripsi yang mencoba membangkitkan daya khayal dari pembaca. Daya khayal pembaca ini dibangkitkan dengan banyaknya digunakan gaya bahasa dalam karangan tersebut. Sedangkan pada deskripsi teknis, kita menceritakan objek yang memang belum ada ketika pembaca melihat atau menemukan objek yang diceritakan dikemudian hari pembaca langsung bisa memahami objek tersebut.

\section{Simpulan}

Berdasarkan hasil penelitian dan pembahasan "Implementasi pendidikan karakter secara terintegrasi dalam pembelajaran menulis karangan deskripsi yang dilakukan di kelas XI TIK SMK Negeri 2 Kepahiang tahun pembelajaran 2015/2016", dapat disimpulkan sebagai berikut:

1. Pada kegiatan perencanaan, pendidikan karakter sudah diimplementasikan secara terintegrasi dengan pembelajaran menulis karangan 
deskripsi. Implementasi tersebut dilakukan dengan cara menuliskan nilainilai pendidikan karakter dalam kolom tersendiri dalam silabus dan Rancangan Pelaksanaan Pembelajaran (RPP) nilainilai tersebut adalah peduli sosial, peduli lingkungan, mandiri, kerja keras, rasa ingin tahu, jujur, semangat kebangsaan, disiplin, kreatif, mandiri, menghargai prestasi, dan demokratis. Selain menuliskan nilai-nilai pendidikan karakter pada kolom tersendiri, pada Rancangan Pelaksanaan Pembelajaran (RPP) nilai pendidikan karakter diintegrasikan pada kegiatan pembelajaran yaitu kegiatan awal, kegiatan inti, dan kegiatan penutup. Nilai pendidikan karakter pada kegiatan awal pembelajaran adalah religius dan tanggung jawab, pada kegiatan inti pembelajaran nilai pendidikan karakter yang dintegrasikan adalah tanggung jawab, kreatif, menghargai prestasi, bersahabat, rasa ingin tahu, dan toleransi. Pada kegiatan akhir pembelajaran nilai pendidikan karakter yg diintegrasikan adalah religius dan mandiri. Untuk itu dalam kegiatan perencanaan pembelajaran implementasi pendidikan karakter sudah dilakukan oleh guru secara optimal.

2. Pada kegiatan pelaksanaan pembelajaran, pendidikan karakter sudah dilimplementasikan secara terintegrasi dengan pembelajaran menulis karangan deskripsi sesuai dengan indikator pelaksanaan pembelajaran dengan integrasi nilai-nilai pendidikan karakter. Nilai-nilai pendidikan karakter yang terdapat dalam kegiatan ini adalah religius, jujur, toleransi, disiplin, kerja keras, menghargai prestasi, bersahabat atau komunikatif, gemar membaca, peduli sosial, dan tanggung jawab. Implementasi pendidikan karakter pada kegiatan pelaksanaan pembelajaran sudah dilakukan oleh guru dengan optimal. Bentuk implementasi pendidikan karakter dalam kegiatan ini adalah dengan ucapan langsung dari guru, tindakan atau prilaku guru dan siswa di dalam kelas selama pembelajaran berlangsung. Oleh sebab itu, pendidikan karakter dalam kegiatan pelaksanaan pembelajaran sudah dilakukan secara optimal oleh guru dan siswa dalam pembelajaran.

3. Pada kegiatan evaluasi, pendidikan karakter diimplementasikan secara terintegrasi dengan pembelajaran menulis karangan deskripsi, implementasi tersebut adalah pada proses evaluasi pembelajaran dengan memberikan tes tertulis dari guru. Bentuk pelaksanaan tes dilakukan secara individu dan berkelompok oleh siswa. Nilai pendidikan karakter yang muncul pada saat siswa mengerjakan tes tertulis secara individu adalah kreatif dan bekerja keras. Sedangkan nilai karakter yang muncul pada saat siswa bekerja dalam kelompok adalah nilai demokratis, rasa ingin tahu, toleransi, dan bersahabat atau komunikatif. Sedangkan evaluasi yang dilakukan oleh guru pada hasil evaluasi kegiatan belajar mengajar belum dilakukan karena guru hanya berorientasi pada hasil pembelajaran yang dilaporkan hanya dalam bentuk angka-angka yang merupakan hasil pembelajaran siswa selama satu semester. Evaluasi yang dilakukan oleh guru menggunakan jenis tes dan hasil akhir dari seluruh kompetensi dasar yang diujikan akan dilaporkan secara berkala setiap semester dalam bentuk laporan hasil belajar siswa dalam bentuk angka- 
angka yang telah ditetapkan dalam Kriteria Ketuntasan Mengajar (KKM), sehingga pada kegiatan evaluasi pendidikan karakter belum diimplementasikan secara optimal karena pembelajaran yang dilakukan oleh guru hanya berfokus pada hasil belajar bukan pada proses pembelajaran.

\section{Saran}

Saran dalam peniltian ini adalah:

1. Guru harus mempersiapkan perencanaan pembelajaran dengan memasukan muatan nilai-nilai pendidikan karakter dalam silabus dan Rancangan Pelaksanaan Pembelajaran. nilai karakter yang harus dituliskan pertama dalam perangkat mengajar tersebut adalah nilai pendidikan karakter religius. Nilai pendidikan karakter religius sangat penting dalam menciptakan suasana pembelajaran yang bermakna dan membuat perubahan sikap siswa.

2. Nilai pendidikan karakter dalam setiap pelaksanaan pembelajaran diharapkan bervariasi disesuaikan dengan indikator pembelajaran yang akan dicapai setelah pembelajaran berlangsung.

3. Evaluasi yang dilakukan pada pembelajaran dengan implementasi pedidikan karakter seharusnya dilakukan oleh guru pada saat proses pembelajaran berlangsung sehingga dapat dipantau kemajuan prilaku siswa. Evaluasi dilakukan juga secara komprehensif dan berkesinambungan selama siswa belajar artinya pembelajaran harus menggunakan penilaian autentik.

4. Hasil kerja siswa seharusnya diberikan penilaian terhadap kebersihan, kerapian, dan ketepatan waktu meyelesaikan menulis karangan deskripsi karangan deskripsi yang dibuat siswa dalam pembelajaran.

5. Diharapkan pihak sekolah memberikan penguatan terhadap kemajuan sikap siswa dengan memberikan program-program khusus yang dapat membentuk karakter siswa baik itu melalui kegiatan ekstrakulikuler maupun intrakulikuler sekolah.

\section{Daftar Pustaka}

Abidin, Yunus. 2012. Pembelajaran Bahasa Indonesia Berbasis Pendidikan Karakter. Bandung: Refika Aditama.

Arikunto, Suharsimi. 2006: Prosedur Penelitian Suatu Pendekatan Praktik. Jakarta: PT. Rineka Cipta.

Dalman. 2012. Keterampilan Menulis. Jakarta: PT. Raja Grafindo Persada.

Damayanti, Dewi. 2014. Panduan Implementasi Pendidikan Karakter Di Sekolah. Yogyakarta: Araska.

Emzir. 2014. Metodologi Penelitian Kualitatif Analisis Data. Jakarta: Rajawali Press.

Fathurrohman, Pupuh, dkk. 2012. Pengembangan Pendidikan Karakter. Bandung: Refika Aditama.

Finoza, Lamuddin. 2004. Komposisi Bahasa Indonesia. Jakarta: Insan Mulia. 
Gunawan, Heri. 2012. Pendidikan Karakter Konsep dan Implementasi. Bandung: Penerbit CV. Alfabeta Bandung.

Harsono, Hanafiah. 2002. Implementasi Kebijakan dan Politik. Bandung: PT. Mutiara Sumber Widya.

Kemendiknas. 2011. Panduan Pelaksanaan Pendidikan Karakter. Jakarta: Badan Penelitian dan Pengembangan Pusat Kurikulum dan Perbukuan.

Keraf, Gorys. 1982. Eksposisi dan Deskripsi Cetakan Kedua. Ende: Nusa Indah

Kusuma, Suherli, 2010. Guru Bahasa Indonesia Profesional. Jakarta: Sketsa Aksara Lalitya.

Mahsun. 2014. Menulis karangan dalam Pembelajaran Bahasa Indonesia. Jakarta: PT. RajaGrafindo Persada.

Milles, Mattew B, dan A. Michael Huberman. 2007. Analisis Data Kualitatif. Jakarta: Universitas Indonesia.

Muslich, Masnur. 2011. Pendidikan Karakter Menjawab Tantangan Krisis Multidimensional. Jakarta: Bumi Aksara.

Nasution. 1988. Metode Penelitian Naturalistik Kualitatif. Bandung: Tarsito.

Sanddhono, Kundharu dan Slamet. 2012. Meningkatkan keterampilan Berbahasa Indonesia. Bandung: KPD (Karya Putra Darwanti Bandung).

Semi, M. Atar. 2003. Menulis Efektif. Padang: Angkasa Raya.
Setiawan, Guntur. 2004. Implementasi dalam Birokrasi Pembangunan. Bandung: Remaja Rosdakarya Offset.

Sugiyono. 2012. Metode Penelitian Kuantitatif Kualitatif dan R\&D. Bandung: Penerbit CV. Alfabeta Bandung.

Sugiyono. 2014. Memahami Penelitian Kualitatif. Bandung: Penerbit CV. Alfabeta Bandung.

Surahmad, Winarno. 1992. Pengantar Penelitian Ilmiah. Bandung: Tarsito.

Usman, Nurdin. 2002. Konmenulis karangan Implementasi Berbasis Kurikulum. Semarang: CV. Obor Pustaka.

Wahyuni, Sri dan Abd. Syukur Ibrahim. 2012. Perencanaan Pembelajaran Bahasa Berkarakter. Bandung: Refika Aditama.

Widyamartaya, A. 1992. Seni Menuangkan Gagasan Cetakan Kedua. Yogyakarta: Karnisius.

Zuchdi, Damiyati, dkk. 2013. Model Pendidikan Karakter Terintegrasi Dalam Pembalajaran Dan Pengembangan Kultur Sekolah. Jakarta: CV. Multi Presanndo.

Zusnani, Ida. 2013. Manajemen Pendidikan Berbasis Karakter Bangsa. Bantul: Platinum. 